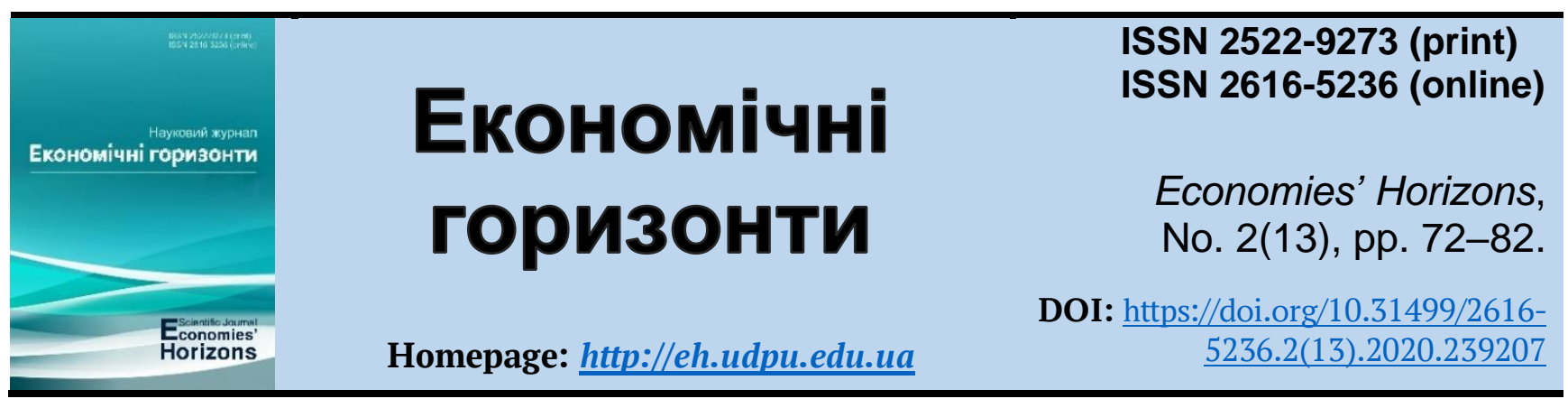

UDC 332:65.012.34

\title{
The organizational and functional model of innovative transformation of regional transport and logistics systems Anatolii A. Nosar ${ }^{1}$
}

Received: 11 May 2020 Accepted: 15 June 2020
Nosar, A. A. (2020), "The organizational and functional model of innovative transformation of regional transport and logistics systems", Economies' Horizons, no. 2(13), pp. 72-82, doi: https://doi.org/10.31499/2616-5236.2(13).2020.239207.

Abstract. The purpose of the paper is to substantiate an organizational and functional model of innovative transformation of regional transport and logistics systems. Methodology. The theoretical and methodological basis of the study is the scientific works of scientists in the study of an organizational and functional model of innovative transformation of regional transport and logistics systems. To achieve the goal set in the paper, the following research methods were used: a system analysis to systematize the organizational and functional model of innovative transformation of regional transport and logistics systems; methods of statistical analysis to determine the share of the use of IT technologies in enterprises by type of economic activity "Transport, warehousing. Postal and courier activities"; for the distribution of transport and logistics enterprises by technological innovations, \% to the total number of enterprises with technological innovations in 2016-2018. Results. The paper discovered that the development of warehousing logistics is primarily a business problem and the state and regional policy in the field of transport, logistics, innovation and investment has a significant impact on the development and innovative development of warehousing systems. Thus, it is important to pay more attention to the mechanisms of implementation of international standards and norms in the areas of customs control, technical and service standards, information security, technology transfer and other normative documents, their unification with those in force in the EU, which will accelerate the integration of transport and logistics systems and promote the rapid introduction of innovations. The organizational and functional model of innovative transformation of regional transport and logistics systems is substantiated, which specifies the distribution of tasks and priorities innovation and development of warehousing logistics with their distribution at the macro level, regional level and sectoral level. The definition of main functions and expected effects will promote the intensification of innovative development, engineering and reengineering of warehouses and transport and logistics entities in general and the construction of modern logistics centers that will provide high-quality services using the latest technologies. Practical tasks. At the regional level, it is important to build effective communication with the business environment, simplify and optimize regulatory activities, improve the business climate and develop mechanisms to stimulate investment in the development of transport and logistics systems, especially in poor areas. Prospects for further research. Economic substantiation of investment support for the development of regional transport and logistics systems.

Keywords: organizational and functional model, transport and logistics systems, warehousing logistics, innovative transformation.

\footnotetext{
${ }^{1}$ International University of Business and Law; PhD candidate; ORCID ID: https://orcid.org/0000-0001-62255277; e-mail: management@nuos.edu.ua; Scientific Adviser - I. O. Irtyshcheva, Doct. Ec. Sc., Professor.
} 
JEL Classification: R40, R41, R42.

Number of references: 13; number of tables: 1; number of figures: 2; number of formulas: $\mathbf{0 .}$

\title{
Організаційно-функціональна модель інноваційної трансформації регіональних транспортно-логістичних систем
}

\author{
Анатолій Анатолійович Носар ${ }^{1}$
}

Стаття надійшла: 11.05 .2020 Стаття прийнята: 15.06.2020
Nosar A. A. The organizational and functional model of innovative transformation of regional transport and logistics systems. Економічні горизонти. 2020. № 2(13). C. 72-82. DOI: $10.31499 / 2616-5236.2(13) .2020 .239207$.

Анотація. Метою статті $\epsilon$ обгрунтування організаційно-функціональної моделі інноваційної трансформації регіональних транспортно-логістичних систем. Методологія. Теоретичною і методологічною основою дослідження є наукові праці вчених у дослідженні організаційно-функціональної моделі інноваційної трансформації регіональних транспортно-логістичних систем. Для досягнення поставленої в роботі мети були використані такі методи дослідження: системного аналізу - для систематизації організаційно-функціональної моделі інноваційної трансформації регіональних транспортно-логістичних систем; методи статистичного аналізу - для визначення частки використання IT технологій на підприємствах за видом економічної діяльності «Транспорт, складське господарство. Поштова і кур'єрська діяльність»; для розподілу транспортно-логістичних підприємств за технологічними інноваціями, \% до загальної кількості підприємств 3 технологічними інноваціями у 2016-2018 роках. Результати. Визначено, що розвиток складської логістики $є$ у першу чергу проблемою бізнесу, державна і регіональна політика у сфері транспорту, логістики, інноваційної та інвестиційної діяльності здійснює суттєвий вплив на процеси розбудови та інноваційний розвиток складських систем. Саме тому, додаткової уваги потребують механізми імплементації міжнародних стандартів і норм у сферах митного контролю, технічних стандартів та стандартів обслуговування, інформаційної безпеки, трансферу технологій та інших нормативних документів, їх уніфікація з діючими в $Є С$, що прискорить процеси інтеграції транспортно-логістичних систем та сприятиме швидкому впровадженню інновацій. Обгрунтовано організаційно-функціональну модель інноваційної трансформації регіональних транспортно-логістичних систем, що уточнює розподіл завдань і пріоритетів інноваційногозабезпечення розвитку складської логістики з їх розподілом на рівні (мегарівень, макрорівень, регіональний рівень, галузевий рівень) з визначенням основних функцій і очікуваних ефектів від реалізації, які у сукупності сприятимуть активізації інноваційного розвитку, інжинірингу та реінжинірингу складських комплексів і транспортно-логістичних утворень в цілому та побудові сучасних логістичних центрів, що надаватимуть послуги високої якості з використанням новітніх технологій. Практичне значення. На регіональному рівні важливими завданнями є побудова ефективних комунікацій з представниками бізнес-середовища, спрощення та оптимізація регуляторної діяльності, покращення бізнес-клімату та розроблення механізмів стимулювання інвестицій у розвиток транспортно-логістичних систем, особливо на депресивних територіях. Перспективи подальщих досліджень. Економічне обгрунтування інвестиційного забезпечення розвитку регіональних транспортно-логістичних систем.

Ключові слова: організаційно-функціональна модель, транспортно-логістичні системи, складська логістика, інноваційна трансформація.

Кількість джерел: 12; кількість таблищь:1; кількість рисунків: 2; кількість формул: 0.

\footnotetext{
${ }^{1}$ Міжснародний університет бізнесу і права; здобувач; ідентифікатор ORCID: https://orcid.org/00000001-6225-5277; e-mail: management@nиоs.edu.иа; Науковий керівник - I. О. Іртищева, д. е. н., професор.
} 


\section{Introduction.}

In the era of fast delivery, warehousing mechanisms have become critical to the customer experience. With the change of time and technological innovations, warehousing becomes much more than just storing goods. It now covers incoming product storage functions and outbound delivery and packaging orders. By 2023, 52\% of warehouse managers plan to increase investment in technology development, with the bulk of spending going to smart warehouse management systems, realtime inventory tracking solutions, barcode scanners and the Internet of Things (IoT) which will include devices such as media, drones and robotic packaging equipment.

\section{Literature review.}

Among modern specialists-economists, whose researches are devoted to the processes of innovative transformation of regional transport and logistic systems, it is necessary to note scientific works, in particular: Shtykov A.R, Chernetskaya-Biletskaya N.B and Golubenko O.L (Shtykov, Chernetskaya-Biletskaya and Golubenko, 2019), Kopishynska K.O. (Kopishynska, 2020), Kirlyk N.Y. (Kirlyk, 2016) Tkach O.V., Voloshchuk I.A. (Tkach and Voloshchuk, 2014), Hrytsyna L.A., Harun O.A. (Hrytsyna and Harun, 2019) and others. However, the complexity and versatility of this study require substantiation of the organizational and functional model of innovative transformation of regional transport and logistics systems.

\section{Methodology.}

The theoretical and methodological basis of the study is the works in the area of the organizational and functional model of innovative transformation of regional transport and logistics systems. To achieve the goal set in the paper, the following research methods were used: system analysis to systematize the organizational and functional model of innovative transformation of regional transport and logistics systems; methods of statistical analysis to determine the share of the use of IT technologies in enterprises by the type of economic activity "Transport, warehousing. Postal and courier activities "; for the distribution of transport and logistics enterprises by technological innovations, \% to the total number of enterprises with technological innovations in 2016-2018.

\section{Research objectives.}

The purpose of the article is to substantiate the organizational and functional model of innovative transformation of regional transport and logistics systems.

\section{Results and discussions.}

Domestic scientists Shtykov A.R., Chernetska-Biletskaya N.B. and Golubenko O.L. (Shtykov, Chernetska-Biletskaya and Golubenko, 2019) distinguish two areas of innovation in warehousing logistics:

- Innovations in the system of ordering Goods to man (introduction of drones, robots, etc.);

- Innovations in the system of completing orders - Man to product (introduction of technologies such as Pick-by-Voice - voice selection, RFID - radio frequency identification, smart glasses - augmented reality, etc.).

Some progress in the field of digitalization of logistics processes, including warehousing logistics is observed in Ukraine. In particular, most modern companies make extensive use of software (virtual warehouse) to monitor the status and movement of inventory, access to which is provided via the Internet to customers, distributors and other partners of the company. Warehouses of large retail companies and logistics intermediaries are equipped with specialized automated lines, electronic code readers and other technologies to optimize warehouse management. Some changes in the implementation of modern IT technologies in the enterprises of transport and logistics are evidenced by statistical data (Fig. $1)$. 


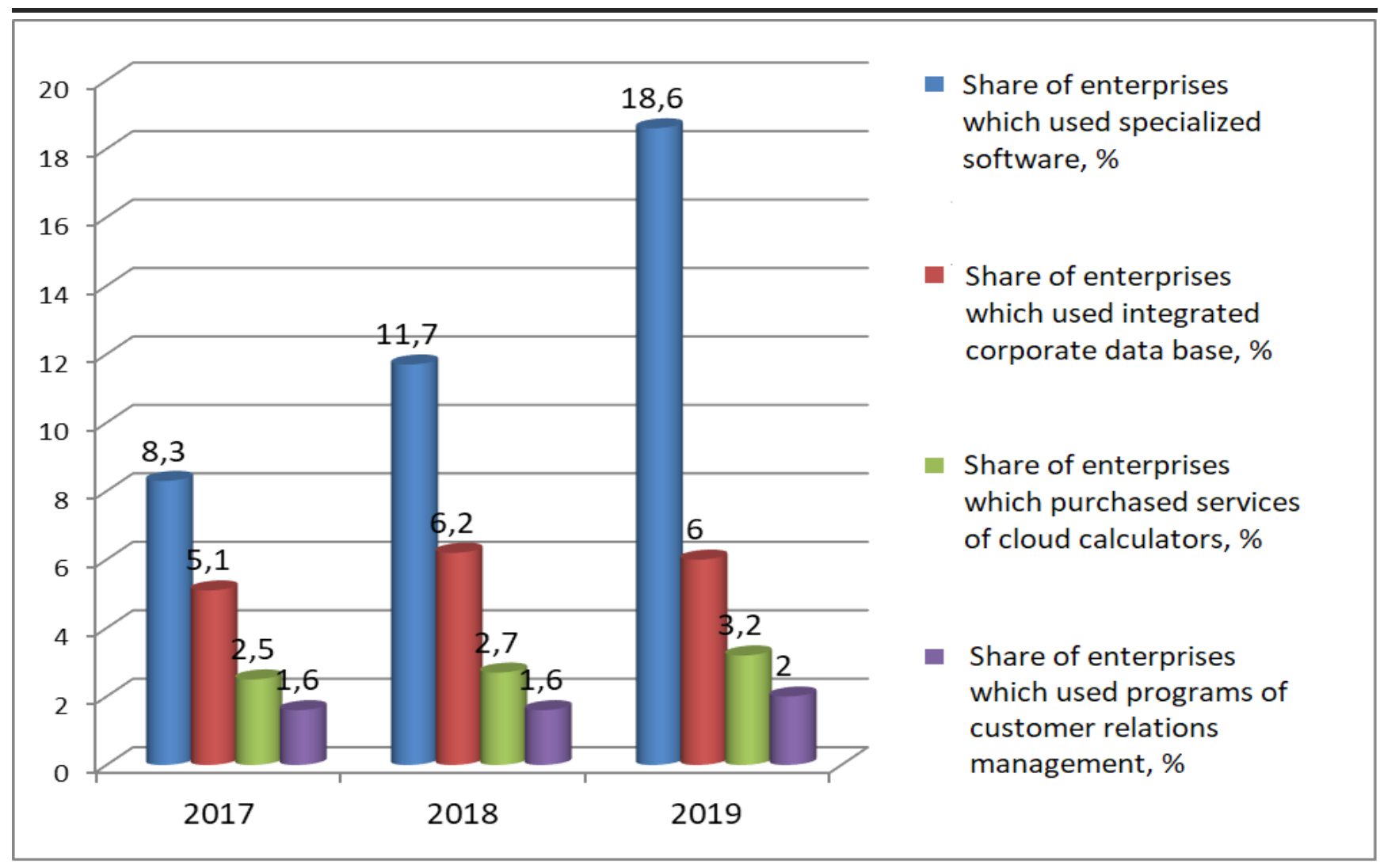

Fig. 1. The use of IT technologies in enterprises by type of economic activity "Transport, warehousing. Postal and courier activities"

Source: calculated by the author according to the State Statistics Service of Ukraine

In recent years, the share of enterprises in the field of transport and logistics services that use specialized software and other types of software has increased significantly. As of the end of 2019 , there were $18.6 \%$ of such enterprises against $8.3 \%$ in 2017 . The use of other types and services of IT is also growing but at a slower pace. It can be stated that the level of digitalization of logistics activities lags significantly behind the level of similar enterprises in developed economies.

Despite significant progress over the past 10 years, in Ukraine, and in particular in some regions, there is a significant shortage of the latest technology and warehouses equipped according to international standards. The potential of information technology is also not fully used due to insufficient funding for innovation, lack of qualified personnel in this area and underdeveloped communication infrastructure in some areas.

According to the research on innovation in the Ukrainian companies "Mind", the rating of innovation of Ukrainian companies showed that in each industry, even within the top five largest companies there are market drivers which change the rules of the game and outsiders, the companies with many bureaucratic procedures that do not produce new inventions. In only five industries out of ten did companies overcome the 75-point threshold, which allowed them to gain innovation status. This indicates low competition and ample opportunities for players who will be able to create new value and bring it to the market.

Thus, the main component of the competitive advantages of transport and logistics centers and systems is active innovation. Unfortunately, analyzing the innovative activity in the field of transport and logistics in Ukraine, a relatively low level of innovative activity of enterprises is discovered. In 20162018, the total number of enterprises that implemented innovations in the field of transport, 
logistics and warehousing was 515 units, which is $112.8 \%$ more than in 2014-2016. However, only 91 of them implemented technological innovations (for comparison, 114 in 2014-2016), which is only $18 \%$. All other companies implemented mainly organizational and marketing innovations.

The main areas of innovation by type of economic activity "Transport, postal and courier activities" are purchase of machinery, equipment and software (65\% of innovations), training of personnel for innovation (18\%) and other areas of innovation (7\%). Figure 2 shows the distribution of enterprises in the transport and logistics sector in the areas of technological innovation in 2016-2018.

The given structure and also dynamics of innovative activity of the transport and logistics enterprises testifies to the essential lag of the logistics operators from similar enterprises of the European level. The exceptions are global logistics operators that enter the Ukrainian market, thereby stimulating competition.
Statistics also show negative trends in the reduction or cessation of innovation by a significant number of enterprises, which is generally the opposite trend compared to the world. The main reason is the lack of own funds, insufficient support of state and regional authorities, whose efforts are focused mainly on the development of infrastructure and repair of roads, significant risk and long payback period of innovative investments.

According to Kopishinska's research, "most of the innovations implemented by logistics companies are related to digital technologies and ICT. However, these companies are technological market leaders and do not fully reflect the trends of the entire industry. The analysis of the use of ICT in the transport and logistics sector by domestic enterprises showed that in 2019 almost $90 \%$ of enterprises use the Internet, only $22 \%$ have their website, and less than $9 \%$ of the total number of enterprises in the sector use cloud computing" (Kopishynska, 2020).

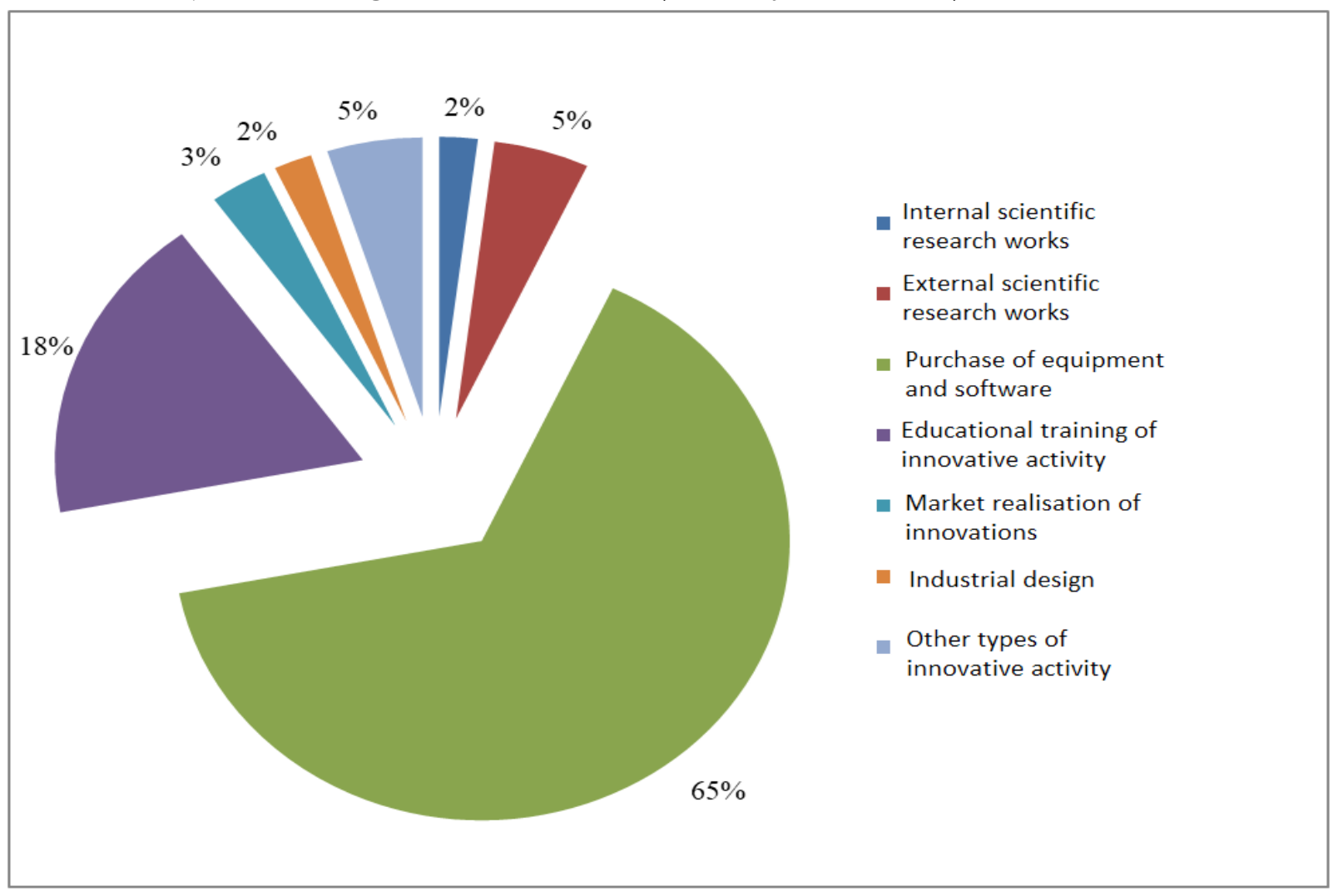

Fig. 2. Distribution of transport and logistics enterprises by technological innovations, \% to the total number of enterprises with technological innovations in 2016-2018 Source: calculated by the author according to the State Statistics Service of Ukraine 
Scientific and technical activities in the field of transport development in logistics in Ukraine are funded under the state strategic priority "Development of new technologies for high-tech development of the transport system, rocket and space industry, aircraft and shipbuilding, armaments and military equipment." In this context, some positive developments should be noted. In particular, according to the Ukrainian Institute of Scientific and Technical Expertise and Information, "Financing of the strategic priority in 2020 compared to 2019 increased 1.7 times and amounted to 19776.43 thousand UAH or $5.9 \%$ (fifth position instead of the sixth in 2019) of the total budget funding of strategic priorities of innovation (2019 4.4\%). All funds were allocated by one administrator - the Ministry of Education and Science, which is aimed at conducting $R \& D$ ("Other"), which indicates a significant increase in demand for enterprises and organizations of the transport sector for innovative developments ". At the same time, the vast majority of funds (93.3\%) is aimed at financing the medium-term priority "Creation of new generations of equipment and technologies in the aerospace, rocket and space industries." That is, the development of transport and, in particular, warehousing logistics, as well as the development and implementation of new technologies in this area, remains a problem primarily for private businesses, not the state.

Ensuring compliance of domestic warehousing logistics and bringing it to the world level of quality requires improvement of state and regional policy in the field of investment and innovation, creation of conditions for attracting foreign investments and unimpeded technology transfer, effective mechanisms of state guarantee and protection of innovative investments. public-private partnership and stock market development. It is equally important to continue the movement towards the implementation of European standards and norms in the field of logistics, simplification of conditions for crossing the customs border, the fight against corruption.

We agree with the opinion of Kopishinska K. that the active implementation of innovations in the field of logistics in enterprises requires support and the creation of appropriate conditions at the highest levels, including international, national, regional and sectoral. Figure 3 shows the main tasks of logistics management at the meta-, macro-and mesolevels, the implementation of which will promote the active implementation of modern innovation trends in the development of transport and logistics companies in Ukraine.

The figure shows the distribution of functions and priorities, the systematic implementation of which will enhance innovative development, engineering and reengineering of warehouses and transport and logistics entities in general and the construction of modern logistics centers that will provide high-quality services using the latest technologies.

The current organizational trends in the development of warehousing logistics can also include the transition of logistics operators to comprehensive services that can be offered to customers. In Ukraine, the gradual transformation of logistics operators from the system of freight transportation to the expansion of service, in particular with the use of digital technologies, is currently underway. 


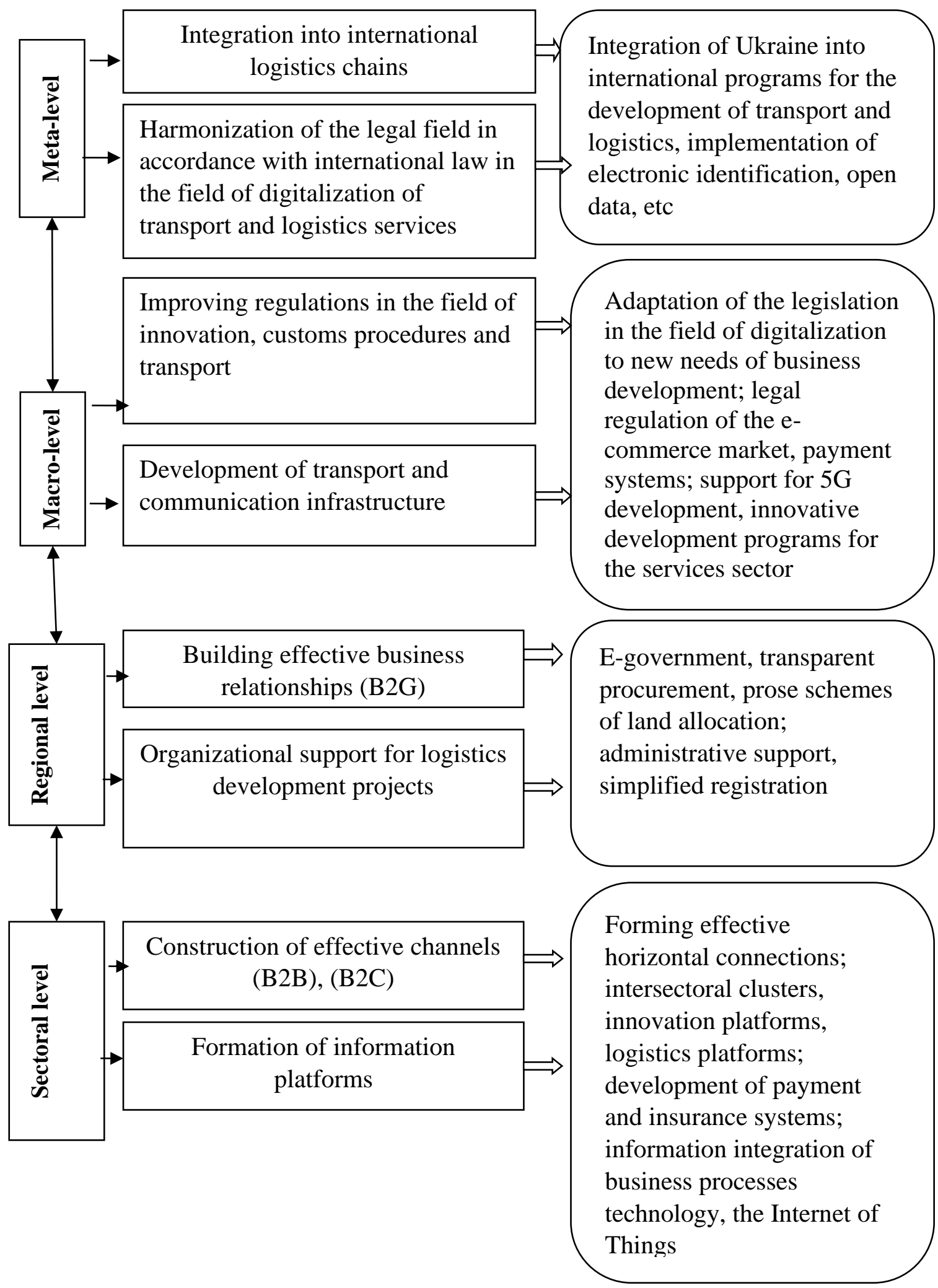

Fig. 3. Organizational and functional model of innovative transformation of regional

Source: systematized by the author transport and logistics systems

Table 1. shows the main characteristics levels of transport and logistics services. of logistics operators in Ukraine in terms of 
Nosar A. A. The organizational and functional model of innovative transformation of regional transport and logistics systems

Table 1. Levels of logistics service in Ukraine

\begin{tabular}{|l|l|l|l|}
\hline Level & \multicolumn{1}{|c|}{ Title } & \multicolumn{1}{|c|}{ Characteristics } & $\begin{array}{l}\text { Examples of Ukrain- } \\
\text { ian companies }\end{array}$ \\
\hline 1PL & $\begin{array}{l}\text { Logistic } \\
\text { insourcing }\end{array}$ & $\begin{array}{l}\text { The type of logistics service, when all } \\
\text { logistics processes are carried out directly by } \\
\text { its carrier on its transport, sp all logistics of } \\
\text { the enterprise is autonomous }\end{array}$ & $\begin{array}{l}\text { The vast majority of } \\
\text { Ukrainian enterprises }\end{array}$ \\
\hline 2PL & $\begin{array}{l}\text { Partial } \\
\text { logistics } \\
\text { outsourcing }\end{array}$ & $\begin{array}{l}\text { The type of logistics activity in which } \\
\text { warehousing and transportation take place } \\
\text { with the involvement of third-party } \\
\text { companies, but at the same time manage the } \\
\text { supply chain independently. At the present } \\
\text { stage in Ukraine, most companies prefer this } \\
\text { type of logistics service }\end{array}$ & $\begin{array}{l}\text { "Intime", "Delivery", } \\
\text { "MistExpress" }\end{array}$ \\
\hline 3PL & $\begin{array}{l}\text { Multipurpose } \\
\text { logistics } \\
\text { outsourcing }\end{array}$ & $\begin{array}{l}\text { 3PL providers are multidisciplinary logistics } \\
\text { providers with highly professional staff. } \\
\text { They are engaged in the delivery of goods, } \\
\text { control of customs clearance, packaging, } \\
\text { packaging of goods, etc. }\end{array}$ & $\begin{array}{l}\text { "Grand } \\
\text { NEOLIT, "Black Sea } \\
\text { Shipping Service Ltd." }\end{array}$ \\
\hline 4PL & $\begin{array}{l}\text { Integrated } \\
\text { logistics } \\
\text { outsourcing }\end{array}$ & $\begin{array}{l}\text { The type of logistics service in which the } \\
\text { customer not only engages an outsourcer to } \\
\text { perform the functions of transport logistics } \\
\text { but also delegates tasks for design and } \\
\text { management of supply chains and logistics } \\
\text { business processes at the enterprise. }\end{array}$ & $\begin{array}{l}\text { Metro Cash \& Carry } \\
\text { Logistik METIK M }\end{array}$ \\
\hline 5PL & $\begin{array}{l}\text { Virtual } \\
\text { logistics }\end{array}$ & $\begin{array}{l}\text { The logistics service that covers the entire } \\
\text { range of logistics services of the global } \\
\text { information technology space }\end{array}$ & $\begin{array}{l}\text { Transnational 4PL and } \\
\text { 5PL providers }\end{array}$ \\
\hline
\end{tabular}

The table shows that Ukrainian logistics activities are gradually developing, some operators improve business processes and offer a wider range of logistics services, competition is also increasing. At the same time, the market potential of transport and logistics systems is significant in the context of transformation processes taking place in the economy, geopolitics and social sphere and it requires more active innovative transformations.

The development of warehousing logistics in the regions involves the introduction of organizational innovations that require integration and coordination of local government, business and state support. In this context, it is worth referring to the experience of countries with developed economies where organizational innovations in the field of transport and logistics are an important tool to ensure the competitive advantages of regions and individual territories.

Transport and logistics centers are important organizational entities that are tied to separate territories and serve for uninterrupted provision of freight, information and financial flows between business entities. As noted by Kirlyk N.Yu., "In European countries, transport and logistics centers are quite common and can be designed in the form of freight centers, activity centers, logistics platforms; logistics nodes; intermodal terminals and other forms. However, transport and logistics centers may differ not only in name but also in the purpose of creation and operation. For example, in Italy, the main purpose of transport and logistics centers is to organize the transportation of goods by sea, and in Germany - the use of the mechanism of interaction of all modes 
of transport "(Kirlyk, 2016).

Studies show that in different parts of Europe, organizational forms as well as mechanisms for financing and investing in the development of transport and logistics infrastructure depend on the economic characteristics of the territory, its geographical location, the predominant types of business. However, the creation of transport centers, junctions of cargo villages and other forms of logistics of territories is recognized as one of the priorities of territorial development and an important component of competitive development.

As noted by Tkach O.V. and Voloshchuk I.A., "a promising area of cooperation in the development of Euro logistics is to attract additional volumes of transit cargo flows through the customs territory of Ukraine. Within the border crossing point on the territory of Ukraine it is expedient to concentrate terminals, warehouses, transhipment complexes and other transport infrastructure, which is necessary for complex processing under customs control of significant volumes of export-import and transit cargo, which will promote Ukraine's accelerated integration efficiency of transit potential use " (Tkach and Voloshchuk, 2014).

In this context, regional authorities should be interested in setting up so-called transport and logistics centers in each region, especially in the areas where the largest transport hubs are concentrated. "Transport and logistics centers/freight villages, as defined by the Euro platform Association, are certain infrastructures that are equipped with all public means to provide a range of services related to all transport activities. A freight village is a certain region of the country, within which various market operators provide the full range of services related to the transport and logistics distribution of goods for both compatriots and international transit "(Bonyar and Korniyko, 2012).

In Ukraine, logistics centers are not singled out as separate objects of transport and logistics infrastructure, and in most cases are identified with a set of professional warehouses, distribution centers, terminals, etc. Lack of established economic ties, unified software, diversity of terminal and space owners create barriers to active innovation and create competition within the facilities themselves. In addition, most transport and logistics centers (70\%) are concentrated in Kyiv and large cities (Odesa, Lviv, Kharkiv, Dnipro, partly Mykolaiv). In the regions, logistics operators operate mainly locally, trying to service the current logistics chains on their own in accordance with the concluded contracts.

We agree with the opinion of Hrytsyna L.A. and Harun O.A., "new market requirements can be met by creating a system of transport and logistics centers that minimize logistics costs and increase the efficiency of economic entities. At the same time, in world practice, two main approaches to the development of transport and logistics infrastructure have been formed, which can be conditionally called "European" and "American". The first involves the implementation of an active state policy aimed at improving the efficiency of freight transportation and the development of logistics centers, by providing tax benefits, government subsidies or grants. The second approach is based on the mechanism of market regulation of the logistics sector, which minimizes the need for government intervention and encourages private companies and investors to invest in the development of logistics infrastructure " (Gritsyna and Harun, 2019).

Khaustova K.M., Kramarenko I.S. and Arkhangelskaya A.-M. I. believe that the development of programs for the development of transport and logistics infrastructure in the regions requires a detailed assessment of its technical condition, compliance of the number and structure of facilities with the real needs of business development and transit opportunities in the region. At the national level, the main tasks are to ensure effective coordination of organizational, economic, technical and technological interaction of market agents of transport and logistics services and transport and logistics infrastructure to create interregional and transnational synergies in the 


\section{Nosar A. A. The organizational and functional model of innovative transformation of regional transport and logistics systems}

processes of their interaction to provide quality transport and logistics and accompanying services (Khaustova, Kramarenko and Arkhangelskaya, 2019).

The study shows that the introduction of major innovation trends in the development of regional logistics systems is not only a necessary condition for ensuring the competitiveness of domestic logistics operators, as well as the regional economy and the national economy as a whole as it significantly reduces logistics costs of all business entities. and manageability of logistics processes, increasing economic and food security in the region.

\section{Conclusions.}

It was determined that the development of warehousing logistics is primarily a business problem, state and regional policy in the field of transport, logistics, innovation and investment has a significant impact on the development and innovative development of warehousing systems. Thus, the mechanisms of implementation of international standards and norms in the areas of customs control, technical and service standards, information security, technology transfer and other normative documents, their unification with those in force in the EU, which will accelerate the integration of transport and logistics systems and promote the rapid introduction of innovations.

The organizational and functional model of innovative transformation of regional transport and logistics systems is substantiated, which specifies the distribution of tasks and priorities of innovation and development of warehousing logistics with their distribution at the level (meta-level, macro level, regional level, sectoral level) with the definition of main functions and expected effects. They will together promote the intensification of innovative development, engineering and reengineering of warehouses and transport and logistics entities in general and the construction of modern logistics centers that will provide highquality services using the latest technologies.

\section{References}

Shtykov, A.R., Chernetskaya-Biletskaya, N.B., Golubenko, O.L. (2019). “Innovative technologies in warehousing logistics". Logistics management and traffic safety: coll. Science. work scientific-practical. Conf., October 14-16, 2019, Lyman (Donetsk region). pp. 182 - 185.

State Statistics Service of Ukraine (2020), available at: http://www.ukrstat.gov.ua/(Accessed 21 March 2020).

Special project Mind. Index of innovation of Ukrainian companies (2020), available at: https://mind.ua/publications/20203121-mind-innovation-index-2019-shtuchnij-intelekt-ale-piratskij-soft (Accessed 21 March 2020).

Scientific and innovative activity of Ukraine: statistical collection / state statistics service of Ukraine (2019) Kiev, Ukraine

Kopishynska, K. O. (2020). "Current state and prospects of digital transformation of the transport and logistics sector of Ukraine", The electronic scientifically and practical journal "Intellectualization of logistics and supply chain management", v.2, pp.99-110

"Implementation of medium-term priority areas of innovation at the industry level and the results obtained in 2017” (2018). Ministry of Education and Science of Ukraine DNU Ukrainian Institute of Scientific and Technical Expertise and Information. Kyiv, Ukraine.

Khrutba, Yu. S., Paranich, P.G. and Idziev, T.B. (2020). “The current state and features of the market of logistics services in Ukraine", The current state of research and technology in industry, vol.4 (14), pp.129-136

Pryshchepa O. and [all others] (2020), "Optimization of multi-channel queuing systems with a single retail attempt: Economic approach”, Decision Science Letters, Volume 9 Issue 4, pp. 559-564

Kirlik, N.Yu. (2016). "Formation of a single logistics system: an important component of European integration processes", Scientific Bulletin of the International Humanities University. Series: Economics and Management, vol. 22, pp. 98-101.

Weaver, O.V., Voloshchuk, I.A. (2014). "Formation of a single logistics system: an important component of European integration processes", Scientific Bulletin of Kherson State University, vol. 9. Part 1, pp. 208212. 
Bonyar, S.M., Korniyko, J.R. (2012). "International experience in creating multimodal transport and logistics centers”, Economy and state, vol.3, pp.32-35

Gritsina, L.A., Harun, O.A. (2019). "Comparative analysis of the development of transport and logistics systems of leading countries", Bulletin of Khmelnytsky National University, vol.2, pp. 143-146

Haustova, K.M., Kramarenko, I.S. and Arkhangelsk, A.-M. I. (2019). “The role of investment in the development of the transport and logistics system of Ukraine", Economy and society: electronic scientific professional journal, vol.20, pp. 456- 462

Цей твір ліцензовано на умовах Ліцензії Creative Commons «/з Зазначенням Авторства - Некомериійна 4.0 Міжнародна» (CC BY-NC 4.0). This is an open access journal and all published articles are licensed under a Creative Commons "Attribution-NonCommercial 4.0 International" (CC BY-NC 4.0). 